\title{
Novel and emerging therapies for B cell lymphoma
}

\author{
Sabarish Ayyappan ${ }^{*}$ and Kami Maddocks
}

\begin{abstract}
Lymphomas are a heterogeneous group of lymphoproliferative disorders, with unique clinical and biological characteristics that exhibit variable response to therapy. Advances in chemo-immunotherapy have improved outcomes in a number of lymphoma subtypes; however, the prognosis for many patients with relapsed and refractory disease remains poor. Novel therapies including several small molecule inhibitors and chimeric antigen receptor $T$ cells have been approved for the treatment of different lymphoma subtypes at relapse, changing the therapy landscape and further improving survival in many of these diseases. This has led to a focus on the development of new cellular therapy, antibody-based therapy, and small molecule inhibitors for relapsed and refractory disease that offer an alternative approach to cytotoxic chemotherapy. We will review these promising novel therapies and discuss their safety and efficacy in first in human studies.
\end{abstract}

Keywords: Lymphoma, First in human study, Immunotherapy, Cellular therapy

\section{Background}

Lymphomas, including Hodgkin (HL) and non-Hodgkin lymphoma (NHL), are a heterogeneous group of B cellderived lymphoproliferative malignancies with varying patterns of clinical behavior and treatment responses. Given the progress in the understanding of different disease biology, the discovery of newer treatments has resulted in increased survival. More effective chemotherapy regimens, newer monoclonal antibodies, radio-immunotherapy, and adoptive $T$ cell therapy have improved the management of lymphomas. However, there are patients who relapse and are refractory to conventional therapy options requiring novel approaches. Herein, we present some early results of first in human studies utilizing promising new approaches to relapsed and refractory $(\mathrm{r} / \mathrm{r})$ lymphomas.

\section{Immunotherapy}

Recent advances in cancer immunotherapy have improved outcomes in advanced malignancies including lymphomas [1-3]. In healthy individuals, the host immune system plays a central role in the diagnosis and prevention of cancer through identifying self and foreign

* Correspondence: Sabarish.ayyappan@osumc.edu

Division of Hematology, Department of Internal Medicine, Arthur G. James Comprehensive Cancer Center, The Ohio State University Wexner Medical Center, 320 W 10th Street, A342 Starling Loving Hall, Columbus, Ohio 43210, USA

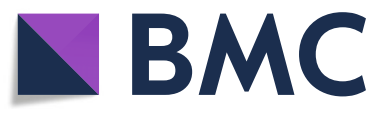

antigens and malignant cell elimination [4]. However, malignancies evade the immune system through alteration of surface antigen expression and T cell exhaustion [5]. Earliest success with immune modulation for lymphoma management has been demonstrated with allogeneic stem cell transplantation through graft versus lymphoma effect, which has been shown to be effective in various histologies of NHL. Novel effective immune modulation can be directed through adoptive cellular therapy and immune cell-targeted monoclonal antibodies.

\section{Adoptive cellular therapy}

Adoptive cellular therapy is a form of immunotherapy that involves ex vivo manipulation of autologous $\mathrm{T}$ cells followed by reinfusion which produces an immune-mediated tumor response. Early work in this field involved the discovery of tumor infiltrating lymphocytes (TIL), a subset of T lymphocytes targeting tumor-specific antigens. Tumor-specific antigens are necessary for tumor recognition by $\mathrm{T}$ cells and activation for tumor killing. T cell receptors (TCRs) are expressed on the surface of T cells and play a central role in the function of the adaptive immune system. TCRs can be engineered with epitope-specific activity for tumor recognition, $\mathrm{T}$ cell activation, and avoiding auto-immunity [6]. However, their function is limited by their ability to identify only short peptides and poor recognition of modifiers

(C) The Author(s). 2019 Open Access This article is distributed under the terms of the Creative Commons Attribution 4.0 International License (http://creativecommons.org/licenses/by/4.0/), which permits unrestricted use, distribution, and reproduction in any medium, provided you give appropriate credit to the original author(s) and the source, provide a link to the Creative Commons license, and indicate if changes were made. The Creative Commons Public Domain Dedication waiver (http://creativecommons.org/publicdomain/zero/1.0/) applies to the data made available in this article, unless otherwise stated. 
including glycosylation and, thus, can fail to identify multiple tumor antigens [6]. Antibody-derived recognition is not hampered by the peptide length and does not require antigens to be presented along with major histocompatibility complex (MHC) molecules. The chimeric antigen receptor (CAR) therapy has been designed by combining the antibody derived extracellular antigen-detecting domain with an intracellular domain providing TCR signaling to activate $\mathrm{T}$ cells.

\section{CAR $T$ cell therapy}

CAR $\mathrm{T}$ cell therapies are engineered from autologous $\mathrm{T}$ cells by genetic modification to express a CAR that consists of a transmembrane protein with an extracellular antigen recognition domain to identify cancer cells, a transmembrane hinge, and an intracellular signaling domain for $\mathrm{T}$ cell activation. The autologous $\mathrm{T}$ cells from a patient are modified to express the chimeric protein, expanded in vivo, and reinfused into the patient. CAR T cells can recognize the tumor antigen, independent of the major histocompatibility complex and activate $\mathrm{T}$ cells leading to tumor cell death. Current CAR $\mathrm{T}$ cells utilize co-stimulatory molecules like CD-28, 4-1BB for the T cell proliferation and survival, producing a persistent antitumor effect. Recently, the U.S. Food and Drug Administration (FDA) approved CAR T cell therapies targeting CD-19 as the tumor antigen: tisagenlecleucel for recurrent pediatric acute lymphoblastic leukemia (ALL) [7] and $r / r$ large B cell lymphoma $[8,9]$ and axicabtagene ciloleucel for $r / r$ large B cell lymphoma [10, 11]. Lisocabtagene maraleucel is another CAR $T$ cell product targeting the CD-19 antigen that has breakthrough designation from the FDA and has shown promising results in early trials [12]. Table 1 compares the properties, efficacy, and safety data from early phase trials for the three CAR T cell therapies in lymphoma.

Currently, there are more than 200 clinical trials evaluating the role of CAR T cells in lymphoma. Severe toxicities including life-threatening cytokine release syndrome (CRS) and neurologic dysfunction vary according to the CAR T cell product. These toxicities occurred in the early phase clinical trials $[9,11]$ and require specialized management. The challenge remains in predicting patients who will have these toxicities and early recognition and management of these toxicities outside of a specialized center (or a large academic center). Financial toxicity related to pricing and reimbursement of CAR T cell therapy remains unresolved.

\section{Redesigned CAR T cell therapy}

Despite the excellent responses seen with CAR $\mathrm{T}$ cell therapy, the toxicities including CRS and neurotoxicity remain a challenge. Varying rates of grade 3 CRS and neurotoxicity have been reported in CAR T cell studies for $\mathrm{r} / \mathrm{r}$ diffuse large $\mathrm{B}$ cell lymphoma (DLBCL) ranging from $13-14 \%$ CRS, 7-28\% neurologic dysfunction, and two deaths from these toxicities $[9,11]$. These are secondary to rapid in vivo $\mathrm{T}$ cell expansion, systemic

Table 1 CAR T cell therapy in lymphoma

\begin{tabular}{|c|c|c|c|}
\hline CAR T cell product & Axicabtagene ciloleucel (Yescarta) & Tisagenlecleucel (Kymriah) & Lisocabtagene maraleucel \\
\hline Costimulation domain & CD-28 & $4-1 B B$ & $4-1 B B$ \\
\hline Vector & Retrovirus & Lentivirus & Lentivirus \\
\hline Conditioning regimen & Fludarabine, cyclophosphamide & $\begin{array}{l}\text { Fludarabine, cyclophosphamide, } \\
\text { or bendamustine }\end{array}$ & Fludarabine, cyclophosphamide \\
\hline Pivotal trial & ZUMA-1 (N = 108) & JULIET $(N=111)$ & TRANSCEND-NHL-001 $(N=102)$ \\
\hline Histology & $\mathrm{DLBCL}, \mathrm{tFL}, \mathrm{PMBCL}$ & $\mathrm{DLBCL}, \mathrm{tFL}$ & $\mathrm{DLBCL}, \mathrm{PMBCL}, \mathrm{FL}, \mathrm{tFL}$ \\
\hline CAR T cell dosage & $2 \times 10^{6}$ cells $/ \mathrm{kg}$ & $3 \times 10^{8}$ cells $/ \mathrm{kg}$ & $1 \times 10^{8}$ cells $/ \mathrm{kg}$ \\
\hline ORR & $83 \%$ & $52 \%$ & $75 \%$ \\
\hline$C R$ & $58 \%$ & $40 \%$ & $55 \%$ \\
\hline Median DOR (months) & 11.1 (95\% Cl, 4.2-NE) & NR (95\% Cl, 10—NR) & NA \\
\hline Overall survival & 24-month survival, 50.5\% (95\% Cl 40.2-59.7) & 11.7 months (95\% Cl, 6.6-NE) & NA \\
\hline Any grade CRS/NT & $93 \% / 64 \%$ & $58 \% / 21 \%$ & $37 \% / 25 \%$ \\
\hline Grade $\geq 3$ CRS & $13 \%$ & $22 \%$ & $1 \%$ \\
\hline Grade $\geq 3$ NT & $28 \%$ & $12 \%$ & $15 \%$ \\
\hline Tocilizumab/steroid usage & $43 \% / 27 \%$ & $15 \% / 10 \%$ & $17 \% / 21 \%$ \\
\hline Grade 5 AEs & $4 \%$ & None & None \\
\hline Reference & {$[11,13]$} & {$[9,14]$} & {$[12,15]$} \\
\hline
\end{tabular}

Abbreviations: $N$ number of patients, $O R R$ overall response rate, $C R$ complete response rate, $C R S$ cytokine release syndrome, $N T$ neurotoxicity, $D O R$ duration of response, $C A R$ chimeric antigen receptor, $A E$ adverse event, $D L B C L$ diffuse large $B$ cell lymphoma, $t F L$ transformed follicular lymphoma, $F L$ follicular lymphoma, $P M B C L$ primary mediastinal $B$ cell lymphoma, NE not estimated, NR not reached, NA data unavailable 
perturbation of the immune system with release of inflammatory cytokines, and endothelial damage causing disruption of blood-cerebrospinal fluid barrier [16]. A novel approach to mitigate the risk for CRS has been to channel signaling via an endogenous CD-3 complex along with a redesigned $\mathrm{T}$ cell activating antigen receptor to regulate the cellular responses after activation. The ARTEMIS ${ }^{\text {Th }}$ signaling platform has been coupled with Eureka's human anti-CD-19 antibody, ET190L1, and this novel complex is expressed on primary $\mathrm{T}$ cells through genetic modification [17]. In vitro, the re-engineered complex has been able to retain the potency and has shown a significant reduction in cytokine release during antigen-specific $\mathrm{T}$ cell activation [17]. In comparison to CAR T cells, in-vitro studies of ARTEMIS $^{\text {TM }} \mathrm{T}$ cells secreted less cytokines including interleukin (IL)-2, interferon- gamma (IFN- $\gamma$ ), granulocytemonocyte colony stimulating factor (GM-CSF), and tumor necrosis factor alpha (TNF- $\alpha$ ) [17]. They also demonstrated less propensity for $\mathrm{T}$ cell exhaustion compared to CAR T cells. The engineered $\mathrm{T}$ cells were given in first in human clinical studies and initial reports of 21 heavily pretreated $\mathrm{r} / \mathrm{r}$ B cell lymphoma patients shows a favorable safety profile with no CRS or neurotoxicity reported [18]. At a median follow-up of 3 months (range 1-8 months), 21 patients completed the first month efficacy assessment with $52 \%$ overall response rate (ORR). Five of the six patients with complete response (CR) remained in CR at the end of 6-month assessment [19]. Plasma levels of cytokines IL-2, 4, 6, 8, 10, IFN- $\gamma$, and TNF- $\alpha$ and GM-CSF were below levels of detection post-treatment. Patients with $\mathrm{r} / \mathrm{r}$ lymphomas have been treated at three different dose levels, with good response and no serious adverse events (SAE) leading to treatment discontinuation, CRS, or neurotoxicity. This novel $\mathrm{T}$ cell platform appears to have promising efficacy in $\mathrm{r} / \mathrm{r}$ NHL with a favorable toxicity profile with no CRS and neurotoxicity seen.

\section{Bispecific CAR T cells}

Relapses and resistance to CAR $\mathrm{T}$ cell therapy may be secondary to antigen escape and low level of antigen expression in CD-19 positive and CD-22 positive tumors [20-22]. Targeting multiple antigens can minimize the risk of antigen escape and improve the on-tumor specific effect by CAR T cell therapy. The advantage of a bispecific CAR $T$ cell stems from the probability of loss of two different antigen targets is low and the bispecific CAR T cell has improved avidity to dual antigen-positive cancer cells compared to a monospecific CAR T cell, in particular at low antigen densities. In a phase 1 study, a bispecific CAR T cell targeting CD-19 and CD-22 has been evaluated in seven patients of which five had DLBCL and two had ALL [23]. Among the patients with DLBCL, the ORR was $80 \%$ with a $40 \%$ CR. No grade 3 adverse events (AE) were reported; however, six patients developed reversible CRS and three patients developed neurotoxicity [23]. Given tolerable toxicity and good efficacy, a dose escalation and expansion study with 60 patients is planned. A different bispecific CAR T cell product targeting CD-19 and CD-20 has been evaluated in r/r NHL with mantle cell lymphoma (MCL), DLBCL, and chronic lymphocytic leukemia (CLL) in two escalating doses in a phase 1 study [24]. The ORR was 50\% including 33\% CR and no grade 3 neurotoxicity or CRS was reported. Two patients developed grade 1-2 CRS and neurotoxicity. No DLTs were reported.

A bispecific CAR T cell targeting CD-19 and CD-22 is currently being studied in a phase 1 study, and enrolled patients will receive 3 doses of consolidation therapy with the anti-programmed death (PD) 1 monoclonal antibody pembrolizumab [25]. Six patients with $r / r$ DLBCL and two patients with transformed follicular lymphoma (tFL) and transformed marginal zone lymphoma were treated with this novel bispecific CAR T cell in escalating doses in a phase 1 study [25]. One patient developed grade 3 neurotoxicity which was reversible and one patient developed grade 2 CRS with other grade 3 toxicities listed in Table 2. Four out of five patients responded with an ORR of $80 \%$ and $40 \%$ CR. Escalation to higher doses and updated follow-up of patients is being planned.

\section{Armored CAR T cells}

The weak activity of CD-19-specific CAR T cells in NHL relative to ALL has been attributed to lack of persistence and expansion of CAR T cells and the blockage of function by the immune-suppressive microenvironment. The anti-CD-19 (19-28z/4-1BBL) "armored" CAR T cells have been engineered with both CD-28 and 4-1BB costimulation for increased tumor removal, continued $\mathrm{T}$ cell proliferation, and persistence [29]. In comparison to second-generation $19-28 \mathrm{z}$ or $19-4-1 \mathrm{BBz}$ CAR T cells, they achieve greater proliferation, IL-2 secretion, and persistence [29]. In a phase 1 trial, 25 patients with $\mathrm{r} / \mathrm{r}$ NHL including de novo DLBCL, CLL, tFL, follicular lymphoma (FL), Waldenström's macroglobulinemia (WM), and Richter's transformation received varying doses of "armored" CAR-T cells, including 16 patients at the highest dose level 4 [3 $310^{6}$ CAR T cells/kg] [26]. Fifty-seven percent (12 of the 21 patients) achieved CR, and at a median follow-up of 93 days (range, 30-439 days), 11 of the 12 patients remain in CR. CAR $T$ cells were detected beyond 160 days. Sixteen patients experienced grade 1-2 CRS (67\%) and no patient experienced severe CRS. Neurotoxicity rates were lower with only two patients developing reversible grade 3 neurotoxicity (8\%). The armored CAR T cells appear efficacious with tolerable toxicity profile and encouraging responses in NHL. 
Table 2 Cellular therapies

\begin{tabular}{|c|c|c|c|c|c|c|c|}
\hline Cellular therapy & $N$ & Patient population & ORR & $C R$ & Grade 3 CRS/NT & Grade 3 AE & Ref \\
\hline ET190L1-Artemis ${ }^{\text {TM }}$ Therapy & 21 & $\begin{array}{l}\mathrm{DLBCL}, \mathrm{FL}, \mathrm{MCL}, \mathrm{SLL} / \mathrm{CLL} \text {, } \\
\text { splenic MZL }\end{array}$ & $52 \%$ & $24 \%$ & None & $\begin{array}{l}\text { Lymphopenia, neutropenia, } \\
\text { tremor, fever, rash }\end{array}$ & [19] \\
\hline Bispecific CAR (CD-19/CD-20) & 7 & DLBCL, ALL & $60 \%$ (DLBCL) & $40 \%$ (DLBCL) & None & None & [23] \\
\hline Bispecific CAR (CD-19/CD-20) & 6 & $\mathrm{DLBCL}, \mathrm{FL}, \mathrm{MCL}, \mathrm{CLL}$ & $50 \%$ & $33 \%$ & None & None & [24] \\
\hline Bispecific CAR (CD-19/CD-22) & 6 & $\mathrm{DLBCL}, \mathrm{tFL}, \mathrm{tMZL}$ & $80 \%$ & $40 \%$ & 1 patient (20\%)—NT & $\begin{array}{l}\text { Neutropenia, } \\
\text { thrombocytopenia, } \\
\text { hypophosphatemia, } \\
\text { neurotoxicity }\end{array}$ & [25] \\
\hline Armored CAR T cells & 25 & $\mathrm{DLBCL}, \mathrm{CLL}, \mathrm{tFL}, \mathrm{FL}, \mathrm{WM}$ & $72 \%$ & $57 \%$ & 2 patients (8\%)—NT & Neurotoxicity & [26] \\
\hline ACTR 087 & 7 & $r / r N H L$ & $50 \%$ & $33 \%$ & None & Neutropenia, leukopenia & [27] \\
\hline ACTR 707 & 6 & $\mathrm{DLBCL}, \mathrm{FL}$ & NA & $50 \%$ & None & Febrile neutropenia & [28] \\
\hline
\end{tabular}

Abbreviations: $N$ number of patients, ORR overall response rate, $C R$ complete response rate, $C R S$ cytokine release syndrome, $N T$ neurotoxicity, $A E$ adverse events, $D L B C L$ diffuse large B cell lymphoma, CLL chronic leukemic leukemia, $t F L$ transformed follicular lymphoma, $F L$ follicular lymphoma, WM Waldenström's macroglobulinemia, $M C L$ mantle cell lymphoma, $t M Z L$ transformed marginal zone lymphoma, $A L L$ acute lymphoblastic leukemia, NHL non-Hodgkin lymphoma, MZL marginal zone lymphoma, NA data unavailable

\section{Antibody-coupled T cell therapy}

The loss of targeted antigen is one of the causes for treatment failure with CAR T cell therapy [30]. Targeting more than one tumor antigen can mitigate this and has been proven in pre-clinical models. The antibody-coupled $\mathrm{T}$ cell receptor (ACTR) platform is a novel engineered $\mathrm{T}$ cell therapy, composed of an extracellular domain of CD-16 linked to CD-3 signaling and 4-1BB co-stimulatory domains, and this mediates anti-tumor activity in combination with tumor-targeted antibodies [31]. The $\mathrm{T}$ cell through the CD-16 ectodomain binds to the Fc receptor in the antibody attached to the tumor antigen by the Fab portion. The $\mathrm{T}$ cells are activated by antibodies bound to tumor antigen and cause $\mathrm{T}$ cell activation, proliferation, and cytotoxic attack of target cells. The same ACTR T cell can kill different types of cancer cells in the presence of the right targeting antibody. Various antibodies including rituximab and transtuzumab along with ACTR $\mathrm{T}$ cells have shown excellent responses and tumor cell cytotoxicity in preclinical models [32]. In a phase 1 study for $r / r$ aggressive CD-20 positive NHL, seven patients received ACTR087 in combination with rituximab at the first dose level [27]. At this level, there were no SAE and other notable toxicities including CRS, neurotoxicities, or autoimmune syndromes were not seen. Cytopenias were the most common AE. Out of the six patients evaluable for response, two patients achieved $\mathrm{CR}$ and one had a partial response (PR). Further dose escalation continues with enrollment of patients at dose level 2 .

Another product, ACTR707, has been designed with a modified ACTR construct containing a CD-28 costimulatory domain instead of a 4-1BB co-stimulatory domain. In a phase 1 study for $\mathrm{r} / \mathrm{r}$ NHL, six patients have been enrolled at the first dose level [28]. No dose-limiting toxicities have been reported among the four evaluable patients and a 50\% CR has been observed. No CRS, autoimmune $\mathrm{AE}$, or severe neurotoxicity was observed.

\section{Antibody-based therapies}

Antibody-based therapies target tumor cells selectively through specific receptors or a distinct antigen expressed by the tumor. The discovery of the anti-CD-20 antibody rituximab has had a dramatic impact in the management of $\mathrm{B}$ cell lymphomas and immune-mediated disorders. Several newer antibodies have been approved for management of other malignancies. Newer antibodies against different target antigens and antibody-drug conjugates, which have been developed by combining targeted antibody with chemotherapy, are listed in Table 3 and will be discussed below.

\section{Bispecific $T$ cell antibodies}

$\mathrm{T}$ cell bispecific antibodies have been engineered to redirect immune effector $\mathrm{T}$ cells to eliminate malignant $\mathrm{B}$ cells, as a newer strategy in lymphomas. This approach is promising due to the synergy and complementary mode of combining $\mathrm{T}$ cell-mediated cytotoxicity with antibody-dependent cellular cytotoxicity (ADCC) [44]. However, in clinical practice, it is limited by infusion reactions, CRS, central nervous system toxicity, shorter half-lives, and need for continuous infusions.

Blinatumomab is a $\mathrm{T}$ cell-engaging bispecific (TCB) antibody which simultaneously links CD-3 and CD-19 antigen. The dual binding is constructed from a CD-19 specific single-chain antibody derived from the variable domains of murine monoclonal antibody HD37 and an anti-CD3 portion derived from murine antibody $\mathrm{L} 2 \mathrm{~K}$ [45]. Using recombinant DNA technology, the two single-chain variable domain fragments are combined by a glycine-serine linker sequence for the production of TCB [46]. The cell lysis by blinatumomab occurs via multiple mechanisms including direct binding to CD-19 and activation of $\mathrm{T}$ cells secreting granzymes and perforin from the synapse between $\mathrm{T}$ cells and target $\mathrm{B}$ cells [47]. In both in vitro and in vivo models, there is strong 
Table 3 Antibody-based therapy

\begin{tabular}{|c|c|c|c|c|c|c|c|c|}
\hline Drug & Antigen target & Class & $\begin{array}{l}\text { Patient } \\
\text { population }\end{array}$ & $N$ & ORR & $C R$ & Grade $3 \mathrm{AE}$ & Ref \\
\hline Blinatumomab & CD-19, CD-3 & Bispecific Ab & $\begin{array}{l}\mathrm{DLBCL} \\
\mathrm{FL}, \mathrm{MCL}\end{array}$ & 35 & $\begin{array}{l}69 \% \\
80 \% \text { (FL) } \\
71 \%(\mathrm{MCL}) \\
55 \% \text { (DLBCL) }\end{array}$ & $\begin{array}{l}37 \% \\
40 \%(F L) \\
43 \%(M C L) \\
36 \%(\mathrm{DLBCL})\end{array}$ & $\begin{array}{l}\text { Leukopenia, } \\
\text { neurologic event }\end{array}$ & [33] \\
\hline Blinatumomab & CD-19, CD-3 & Bispecific Ab & DLBCL & 25 & $36 \%$ & $16 \%$ & $\begin{array}{l}\text { Leukopenia, } \\
\text { thrombocytopenia, } \\
\text { neurologic event }\end{array}$ & [34] \\
\hline CD20-Tcb (RG6026) & CD-20, CD-3 & Bispecific Ab & $\begin{array}{l}\text { DLBCL,PMBCL, } \\
\text { tFL, RT, FL }\end{array}$ & 64 & $38 \%$ & $24 \%$ & None & [35] \\
\hline Mosunetuzumab & CD-20, CD-3 & Bispecific Ab & $\mathrm{DLBCL}, \mathrm{tFL}, \mathrm{FL}$ & 98 & $41 \%$ & $27 \%$ & $\begin{array}{l}\text { Anemia, neutropenia, } \\
\text { hypophosphatemia }\end{array}$ & [36] \\
\hline $\begin{array}{l}\text { Adct-402 } \\
\text { (loncastuximab tesirine) }\end{array}$ & CD-19 & $A D C$ & $\mathrm{MCL}, \mathrm{FL}$ & 30 & $\begin{array}{l}80 \% \text { (FL) } \\
46.7 \% \text { (MCL) }\end{array}$ & $\begin{array}{l}53.3 \%(F L) \\
26.7 \%(M C L)\end{array}$ & $\begin{array}{l}\text { Increased GGT, } \\
\text { neutropenia, } \\
\text { anemia }\end{array}$ & [37] \\
\hline $\begin{array}{l}\text { Adct-301 } \\
\text { (camidanlumab tesirine) }\end{array}$ & CD-25 & $A D C$ & $\begin{array}{l}\text { B cell NHL } \\
\text { T cell NHL }\end{array}$ & $\begin{array}{l}22 \\
17\end{array}$ & $\begin{array}{l}31.3 \% \\
50 \%\end{array}$ & $\begin{array}{l}18.8 \% \\
0 \%\end{array}$ & $\begin{array}{l}\text { Immune-related AE: } \\
\text { dermatitis exfoliative, } \\
\text { thyroiditis }\end{array}$ & [38] \\
\hline $\begin{array}{l}\text { Adct-301 } \\
\text { (camidanlumab tesirine) }\end{array}$ & CD-25 & $A D C$ & $\mathrm{HL}$ & 60 & $38 \%$ & $24 \%$ & $\begin{array}{l}\text { Increased GGT, ALT, } \\
\text { AST, and ALP, } \\
\text { maculopapular } \\
\text { rash, anemia, and } \\
\text { thrombocytopenia; } \\
\text { immune-related } \\
\text { AE: Guillain-Barré } \\
\text { syndrome, thyroiditis }\end{array}$ & [39] \\
\hline MT 3724 & $\begin{array}{l}\text { CD-20, Shiga-like } \\
\text { toxin-I A1 }\end{array}$ & $\begin{array}{l}\text { Recombinant fusion } \\
\text { protein } \mathrm{Ab}\end{array}$ & DLBCL & 24 & $12.5 \%$ & $4 \%$ & None & [40] \\
\hline Hu5F9-G4 & CD-47 & $A b$ & $\mathrm{DLBCL}, \mathrm{FL}$ & 22 & $50 \%$ & $36 \%$ & $\begin{array}{l}\text { Pulmonary embolism, } \\
\text { ITP, anemia, } \\
\text { thrombocytopenia, } \\
\text { neutropenia, pyrexia, } \\
\text { chills }\end{array}$ & [41] \\
\hline DCDS0780A & CD-79b & $\mathrm{ADC}$ & $\begin{array}{l}\text { DLBCL, FL, } \\
\text { MCL, MZL }\end{array}$ & 48 & $40 \%$ & $14 \%$ & $\begin{array}{l}\text { Neutropenia, } \\
\text { thrombocytopenia, } \\
\text { hypercalcemia }\end{array}$ & [42] \\
\hline $\begin{array}{l}177 \text { Lu-lilotomab } \\
\text { satetraxetan }\end{array}$ & CD-37 & $\begin{array}{l}\text { Antibody- } \\
\text { radionuclide } \\
\text { conjugate }\end{array}$ & $\begin{array}{l}\mathrm{FL}, \mathrm{MCL} \\
\mathrm{MZL}, \mathrm{SLL}\end{array}$ & 74 & $61 \%$ & $26 \%$ & $\begin{array}{l}\text { Neutropenia, } \\
\text { thrombocytopenia, } \\
\text { infections }\end{array}$ & [43] \\
\hline
\end{tabular}

Abbreviations: $N$ number of patients, $O R R$ overall response rate, $C R$ complete response rate, $A E$ adverse events, $D L B C L$ diffuse large $B$ cell lymphoma, $C L L$ chronic leukemic leukemia, $t F L$ transformed follicular lymphoma, $F L$ follicular lymphoma, WM Waldenström's macroglobulinemia, $M Z L$ marginal zone lymphoma, $R T$ Richter's transformation, $M C L$ mantle cell lymphoma, $P M B L$ primary mediastinal B cell lymphoma, $A D C$ antibody-drug conjugate, GGT gamma-glutamyl transferase, ITP immune thrombocytopenic purpura, $A E$ adverse event, $A L T$ alanine aminotransferase, $A L P$ alkaline phosphatase, $A b$ antibody

evidence for cytotoxic activity against $\mathrm{CD}-19$ positive $\mathrm{B}$ cells $[48,49]$. A phase 1 trial with blinatumomab dosage starting at $5 \mu \mathrm{g} / \mathrm{m}^{2} /$ day as a continuous infusion enrolled 76 patients with relapsed NHL in an initial dose escalation phase and this was followed by a dose expansion phase at the maximum tolerated dose (MTD) of $60 \mu \mathrm{g} / \mathrm{m}^{2} /$ day [33]. There were no responses noted at doses $\leq 15 \mu \mathrm{g} / \mathrm{m}^{2} /$ day, indicating a dose-response relationship. At the $60 \mu \mathrm{g} /$ $\mathrm{m}^{2}$ /day dose, the ORR was $69 \%$ and CR/complete remission unconfirmed $(\mathrm{CRu})$ was $37 \%$ with long-term remissions noted independent of prior therapies and histologic subtype. Impressive single-agent activity was seen in follicular lymphoma (ORR 80\%), mantle cell lymphoma (ORR 71\%), and DLBCL (ORR 55\%) [33]. Three grade 5
AEs were reported including two deaths related to infection. The most common grade $3 \mathrm{AE}$ were lymphopenia at $69 \%$ and grade 3 neurologic events at $22 \%$ with encephalopathy (8\%), headache (4\%), and aphasia (4\%) being the most common neurologic manifestations. Neurologic events began within the first 2 days of the first infusion and resolved with treatment or discontinuation. These events have been attributed to cytokine-releasing $\mathrm{T}$ cells migrating into the central nervous system (CNS). The therapy-related neurologic events caused frequent discontinuation, and several approaches to mitigate this are being explored including single-stepwise dose escalation with pentosane polysulfate SP54 or double-stepwise dose escalation with corticosteroid prophylaxis. 
A phase 2 study in $r / r$ DLBCL evaluated the safety and efficacy of blinatumomab and reviewed the optimal administration through either stepwise dose escalation to maximal target dose or treatment on a fixed target dose [34]. Twenty-five patients with $\mathrm{r} / \mathrm{r}$ DLBCL were enrolled including 16 patients with refractory disease at baseline. The ORR was $36 \%$ with a CR of $16 \%$ and a median duration of response of 11.6 months. The response rate for refractory patients was lower (ORR 19\%) in comparison to patients with relapsed disease (ORR 67\%). Median PFS was 3.7 months (95\% CI, 1.4-7.7) with median overall survival (OS) of 5 months ( $95 \%$ CI, 2.3 to not estimable). Grade 3 neurologic events reported were encephalopathy (9\%) and aphasia (9\%) with no patient experiencing grade 4 or 5 AEs. Two patients who received the flat target dose $(112 \mu \mathrm{g} /$ day $)$ at therapy initiation developed serious grade 3 neurologic events related to therapy, and one patient developed grade 4 respiratory failure related to therapy and other grade 4 AEs unrelated to therapy including neutropenia and bone marrow toxicity from an acute viral infection were reported. Further enrollment was terminated in this cohort for safety reasons after review by the data monitoring committee. Currently, there are clinical trials evaluating the combination of blinatumomab with other immunomodulatory agents like lenalidomide (NCT02568553) and immune therapies like pembrolizumab (NCT03605589, NCT03340766) in relapsed and refractory lymphoma.

The CD-20-TCB (RG6026) is another TCB antibody designed to bind to CD-20 and CD-3 receptors in a " 2 : 1 " format, with high-avidity binding from two CD-20 binders and a CD-3 binder and strong potency enabled by a head-to-tail orientation and a long half-life [50, 51]. It has potent activity in primary tumor samples, and in vivo, it has shown regression of aggressive lymphoma models [52]. A single dose of obinutuzumab pretreatment has been shown to debulk the disease and abrogate the initial strong CRS associated with $\mathrm{T}$ cell activation [52]. In a phase-1, first in human trial, 47 patients with aggressive $\mathrm{r} / \mathrm{r}$ B cell lymphomas and 17 patients with $\mathrm{r} / \mathrm{r}$ indolent lymphomas received CD-20-TCB at doses ranging from $5 \mu \mathrm{g}$ to $1800 \mu \mathrm{g}$ in an every 2 weeks schedule [35]. The most common AEs included pyrexia, neutropenia, and grade 1-2 CRS in 14 patients. All CRS events were manageable with no central nervous system toxicity reported. CR was noted from $300 \mu \mathrm{g}$ dose onwards after two cycles of therapy in 29 evaluable patients. Investigator-assessed ORR was $38 \%$ with $24 \%$ CR rate and all CRs were sustained at a median follow-up of 96 days (range 26-152).

Mosnetuzumab is a humanized, bispecific antibody that has been developed with activity binding to CD-3 epsilon $(\mathrm{CD}-3 \varepsilon)$ expressed by $\mathrm{T}$ cells and $\mathrm{CD}-20$ expressed in $\mathrm{B}$ cell lymphomas [53]. In in vitro and in vivo studies, it showed activity against normal and malignant B cells and it activated $\mathrm{T}$ cell-dependent (TDB) killing via the granzyme-perforin pathway. It also demonstrated antiCD-20-TDB activity against cell lines with very low CD-20 expression levels and only a transient CRS was noted in the first 24 hour, despite the long half-life for this antibody. In a phase $1 / 1 \mathrm{~b}$ study of $98 \mathrm{r} / \mathrm{r}$ NHL patients, mosunetuzumab was administered in escalating dose design in two different dosing strategies [36]. Sixty-six percent of the patients developed treatment-related AEs, and $22.5 \%$ were grade 3 with the majority events occurring in cycle 1 . Two treatment-related deaths including one secondary to hepatic failure and one from hemophagocytic lymphohistiocytosis from Epstein-Barr virus infection occurred. Responses were noted in patients refractory to prior antiCD-20 and in patients relapsing after CD-19 targeted CAR T cell therapy and are listed in Table 3.

\section{Antibody-drug conjugates}

Antibody-drug conjugates (ADCs) are a novel class of drugs which consist of cytotoxic chemotherapy combined to a target-specific monoclonal antibody via a linker. These combine the cytotoxic potency of chemotherapy with the selectivity of monoclonal antibody to provide a novel safe and effective therapy. Several ADCs have been studied and are in current clinical practice including brentuximab vedotin, inotuzumab ozogamicin, and trastuzumab emtansine.

ADCT-402 is a CD-19-targeted antibody-drug conjugate (ADC) carrying SG3199 which causes cytotoxicity by DNA crosslinking [54]. It is strongly potent and selectively targets CD-19 expressing cell lines and is effective through bystander killing of CD-19 negative cells as well. In a phase 1 , multicenter, open-label, single-arm study, with dose escalation and dose expansion cohorts of $137 \mathrm{r} / \mathrm{r}$ DLBCL patients, 15 to $200 \mu \mathrm{g} / \mathrm{kg}$ of ADCT402 was given for a median two cycles (range 1-13) [55]. The ORR was $40.2 \%$ in 132 evaluable patients with $22 \%$ achieving CR. At a median follow-up of 5.13 months, the median duration of response (DOR) was 4.17 months; although for those achieving CR, the median DOR has not been reached. The most common grade $3 \mathrm{AEs}$ included elevated gamma-glutamyltransferase and cytopenias. ADCT402 has shown good single-agent antitumor activity and the toxicity profile is manageable at doses $\geq 120 \mu \mathrm{g} / \mathrm{kg}$.

CD-25 is expressed by many lymphomas including HL, peripheral $\mathrm{T}$ cell $(\mathrm{PTL})$, cutaneous $\mathrm{T}$ cell $(\mathrm{CTCL})$, and NHL [56]. ADCT-301 (camidanlumab tesirine [Cami-T]) is an ADC containing monoclonal antibody specific for CD-25 conjugated to a pyrrolobenzodiazepine dimer toxin. In vivo studies of ADCT-301 have demonstrated high potency and selective cytotoxicity against CD-25 expressing human lymphoma cell lines [57]. Once internalized, the dimer toxin causes cytotoxic effects through the formation of DNA interstrand cross-links. In a phase 1 
study of 60 patients with heavily pretreated classical HL, dosing ranges from 5 to $300 \mu \mathrm{g} / \mathrm{kg}$ were evaluated [39]. The MTD was not reached; however, $45 \mu \mathrm{g} / \mathrm{kg}$ every 3 weeks was chosen for the dose expansion phase. Analysis of the $45 \mu \mathrm{g} / \mathrm{kg}$ dose group (dose escalation with expansion cohort) showed an ORR of $80.8 \%$ (21/26 pts) and CR rate of 50\% (13/26 pts). The median PFS was 6.7 months and median DOR was 7.7 months. The most common grade 3 AEs noted were liver function abnormalities, anemia, thrombocytopenia, and a maculopapular rash. Grade 3 or higher AEs were seen in 37/60 (61.7\%) patients resulting in treatment discontinuation in 17/60 (28\%) of the patients. Immune-related AEs were reported including two cases of Guillain-Barré syndrome (one each at dose 45 and $60 \mu \mathrm{g} / \mathrm{kg}$ ) and one case of thyroiditis. Although encouraging ORRs were seen in this heavily pretreated HL population, cautious evaluation in further phase 2 studies of this novel ADC will be required given the immune-related AEs.

The ADCT-301 has been evaluated in a phase 1 trial of 39 patients with $\mathrm{r} / \mathrm{r}$ NHL and T cell lymphomas [38]. Dosages evaluated in this population range from 3 to $150 \mu \mathrm{g} / \mathrm{kg}$ with a median number of 2 cycles (range 1-5) and a median treatment duration of 22 days (range 1127). The grade $3 \mathrm{AE}$ profile is similar to the previous study discussed with ADCT-301, and other immunerelated AEs were reported in five patients. However, severe neurological impairment like Guillain-Barré syndrome was not seen. The MTD was not reached, but at doses of $60-150 \mu \mathrm{g} / \mathrm{kg}$, the ORR was $38.5 \%$ (10/26 pts) with $11.5 \% \mathrm{CR}$. The $\mathrm{T}$ cell lymphoma cohort had an ORR of $50 \%$ (all PR), and enrollment in the $60 \mu \mathrm{g} / \mathrm{kg}$ and $80 \mu \mathrm{g} / \mathrm{kg}$ cohorts is ongoing to evaluate the optimal dose for further expansion in each subtype. The B cell lymphoma cohort treated at doses $\geq 60 \mu \mathrm{g} / \mathrm{kg}$ had a less impressive $31 \%$ ORR with $18.8 \%$ CR. This ADC appears to have promising activity in $\mathrm{T}$ cell lymphomas with a tolerable toxicity profile, and further dose evaluation is underway with planned dose expansion at the MTD.

\section{Engineered toxin antibody}

Engineered toxin body (ETB) is a novel recombinant therapy targeting cancer cells combining an immunotoxin scaffold with an antibody fragment binding domain. They are designed to create a targeted response based on antibody binding, intracellular internalization, and ribosomal inhibition by a Shiga-like toxin [58]. This unique delivery platform has been designed to avoid the innate and adaptive immune recognition. MT-3724 is an engineered toxin antibody (ETB) that comprises of a single-chain variable fragment of an antibody targeting CD-20 and a Shiga like toxin subunit A inactivating the ribosomal activity. In a first in human study with MT3724, 24 patients with $\mathrm{r} / \mathrm{r}$ NHL have been treated including 21 patients in 6 dose escalation doses (range from $5-100 \mu \mathrm{g} / \mathrm{kg} / \mathrm{dose}$ ) and three patients in the MTD cohort at $75 \mu \mathrm{g} / \mathrm{kg} /$ dose [40]. Peripheral edema, fatigue, diarrhea, myalgia, and cough were the most common AEs reported. In the dose expansion cohort, two out of three patients developed grade 2 capillary leak syndrome (CLS) leading to dose delay and reduction. The CLS was attributed to obesity and was reversible in all patients. The MTD was reduced to $50 \mu \mathrm{g} / \mathrm{kg} /$ dose and capped at $6000 \mu \mathrm{g} /$ dose. Five DLBCL patients had clinical benefit at $5-75 \mu \mathrm{g} / \mathrm{kg} /$ dose with $1 \mathrm{CR}$ and 2 PR (ORR 12.5\%) and two patients with stable disease demonstrated significant tumor reduction (49\% and 48\% respectively).

\section{Macrophage-mediated phagocytosis}

Hu5F9-G4 is a humanized, monoclonal antibody with anti-CD-47 activity that selectively induces phagocytosis of tumor cells through macrophages by unmasking prophagocytic "eat me" signals [59]. Hu5F9-G4-mediated phagocytosis is augmented by targeted antibodies like rituximab, and in pre-clinical models of lymphoma, the synergistic and durable anti-tumor effects of the combination have been demonstrated [60]. Advani and colleagues reported a phase-1b study of Hu5F9-G4 and rituximab in 22 patients with $\mathrm{r} / \mathrm{r}$ DLBCL and FL who were treated with Hu5F9-G4 at a priming dose of $1 \mathrm{mg} /$ $\mathrm{kg}$ IV followed by escalating weekly maintenance doses of 10 to $30 \mathrm{mg} / \mathrm{kg}$ [41]. Most of the AEs reported were grade 1 and 2, with the most common being chills, anemia, headache, and infusion-related reactions. The ORR was $50 \%$ with $36 \%$ CR. In the DLBCL cohort, ORR was $40 \%$ with $33 \% \mathrm{CR}$, and in the FL patients, ORR was $71 \%$ with $43 \% \mathrm{CR}$. Among patients with a response, 10/11 patients (91\%) had an ongoing response at the time of data cutoff.

\section{Immune checkpoint therapy}

The discovery of immune checkpoints and development of monoclonal antibodies that regulate these has revolutionized the oncology field over the past decade. Tumor immunity involves a multi-step process of antigen presentation, lymphocyte activation, recruitment of lymphocytes to the tumor microenvironment, and, finally, tumor cell death. The $\mathrm{T}$ lymphocyte activation requires the $\mathrm{T}$ cell receptor engagement with $\mathrm{MHC}$ on antigen presenting cells and co-stimulation by $\mathrm{CD}-28$ interacting with B7-1 (CD-80) or B7-2 (CD-86) ligand on malignant cells $[61,62]$. Numerous inhibitory receptors have been discovered, which may disrupt these $\mathrm{T}$ cell and tumor cell interactions and can dampen the activation process. The cytotoxic $\mathrm{T}$ lymphocyte-associated antigen 4 (CTLA-4) found on T cells shares homology with CD-28 and modulates the co-stimulatory signaling by competing with activating ligands like CD-80 and CD-86, expressed by 
antigen presenting cells and thereby suppressing $\mathrm{T}$ cell activation. Similarly, the PD-1 receptor expressed on T cells binding to programmed death ligand 1 (PD-L1) expressed by tumor cells can downregulate the $\mathrm{T}$ cell response. The immune checkpoint inhibitors can interfere with these interactions and activate anti-tumor activity by augmenting $\mathrm{T}$ cell activation. Currently, checkpoint inhibitor therapies targeting one of these ligands have been approved by FDA for treatment of multiple malignancies.

PD-L1 and PD-L2 are expressed by various hematologic malignancies, and in particular, PD ligand expression has been associated with 9p23-24 gene amplification [63]. In Hodgkin Reed-Sternberg cells, the gene amplification causes PD-L1/PD-L2 ligand expression directly and indirectly, from increased JAK2 expression through the JAKSTAT signaling pathway leading to further enhancement of PD ligand expression [64]. The higher frequency of 9p24 gene alteration and increased PD ligand expression makes classical HL responsive to immune checkpoint therapy. Excellent response rates with durable responses have been demonstrated in numerous single-agent studies with nivolumab or pembrolizumab in relapsed and refractory HL $[65,66]$. Both nivolumab and pembrolizumab have been approved by the FDA for treatment of relapsed and refractory classical HL. Although the ORR with PD-1 blockade in $\mathrm{HL}$ is high, the number of patients achieving $\mathrm{CR}$ is low (16-22\%) and there has been progression noted after the initial response $[65,66]$. To improve upon its activity and maintain longer response, combinations including other checkpoint inhibitors like ipilimumab, antibody drug conjugates like brentuximab or chemotherapy have been tested. In a phase 1 study, nivolumab in combination with ipilimumab showed response rates comparable with single-agent nivolumab, with increased toxicities [67]. There are ongoing trials with blockade of other immune checkpoints including lymphocyte-activation gene 3 (LAG-3) in combination with immune checkpoint inhibitors (NCT02061761 and NCT03598608). Immunotherapy in combination with chemotherapy regimens like adriamycin, vinblastine, and dacarbazine (AVD) and in combination with brentuximab has been well tolerated [68, 69]. However, the response rates seen with the combinations were comparable to the activity seen with the respective regimens without the addition of immune checkpoint therapy $[68,69]$ and have not been encouraging.

NHL, unlike HL, have 9p24.1 gene alterations infrequently but the exception to this includes primary mediastinal B cell lymphoma (PMBCL), which shares histologic and genetic characteristics with HL, including 9p24.1 amplification and translocation [63]. Similarly, 9p24.1 copy number gains and translocations have been identified in primary central nervous system lymphoma (PCNSL) and primary testicular lymphomas (PTL), with rearrangement of the regulator elements of TBLX1XR1 leading to increased PD-L2 protein expression [70]. Thus, PMBCL, PCNSL, PTL, and gray zone lymphomas appear to share the genetic basis for immune checkpoint inhibition and suggest a potential role for PD-1 antibodies in these malignancies. In a phase $1 \mathrm{~b}$ study with pembrolizumab in 18 patients with $\mathrm{r} / \mathrm{r}$ PMBCL, the ORR was $41 \%$ with 2 patients achieving CR [71]. There is an ongoing international phase 2 study confirming the efficacy of pembrolizumab in PMBCL and assessing if genetic abnormalities correlate with response (NCT 02576990). A case series of four patients with $\mathrm{r} / \mathrm{r}$ PCNSL and CNS relapse of PTL treated with nivolumab off trial [72] included 100\% ORR after 4 cycles, and at 17 months follow-up, all patients were alive.

The 9p24.1 genetic modification and rearrangements are rare in other lymphomas and PD-L1 expression is poor in aggressive B cell lymphomas [73, 74]. In a phase 1 trial of $r / r$ DLBCL patients, nivolumab showed an ORR of $36 \%$, but the responders had remission less than 3 months [75]. There are a few trials in DLBCL being completed with immune checkpoint inhibitors in combination with anti-CD-20 antibodies (NCT03401853) and immunomodulators and targeted agents like lenalidomide (NCT03015896) and copanlisib (NCT03484819). Follicular lymphomas (FL) do not express PD-L1 ligands or have chromosome 9 modifications, but immune checkpoint expression is prevalent on the TILs or other cells within the tumor microenvironment [76]. The PD-1 expression on the TILs appears to have an effect on progression and transformation risk in FL [77, 78]. Although FL exhibits some responsiveness to immune checkpoint therapy, the responses are significantly lower than seen in HL. Immune checkpoint antibodies in combination with anti-CD-20 antibodies like rituximab and obinutuzumab have demonstrated good tolerability and ORR ranging from 57 to $80 \%[75,79]$ noted in various studies. These responses are comparable to historical controls treated with anti-CD-20 antibodies alone. There are ongoing trials evaluating checkpoint agents in combination with HDAC inhibitor (NCT03179930), radiation (NCT02677155), chemoimmunotherapy (NCT02541565), or personalized tumor vaccine (NCT03121677) in follicular lymphoma.

\section{Small molecule inhibitors}

With recent advances, oncogenic mutations and dysregulation of signaling pathways have been identified as leading to lymphomagenesis and could be potential targets for therapy. We can selectively target these pathways and the molecules that are activated in lymphoma and known to be contributory to the survival of lymphoma cells. We will discuss some promising novel small molecules developed for different subtypes of lymphomas (Table 4). 
Table 4 Small molecule inhibitors

\begin{tabular}{|c|c|c|c|c|c|c|c|}
\hline Drug & Class & Patient population & $N$ & ORR & $C R$ & Grade 3 AE & Reference \\
\hline M7583 & BTK inhibitor & R/R DLBCL, WM, MCL, MZL, SLL & 18 & $50 \%$ & $11 \%$ & Diarrhea & {$[80]$} \\
\hline ME-401 & PI3K $\delta$ & $\mathrm{R} / \mathrm{R} F \mathrm{~L}, \mathrm{CLL}$ & 31 & $83 \%$ & NA & Diarrhea, rash & [81] \\
\hline LAM-002A & Endosomal protein inhibitor & R/R DLBCL, MCL, FL, MZL, CLL & 24 & NA & NA & Tumor lysis syndrome & [82] \\
\hline INCB057643 & BET protein inhibitor & $\mathrm{R} / \mathrm{R} F \mathrm{~F}, \mathrm{DLBCL}$ & 5 & $33 \%$ (DE) & None & $\begin{array}{l}\text { Hyperglycemia, } \\
\text { thrombocytopenia, } \\
\text { anemia, hyperbilirubinemia, } \\
\text { Increased INR }\end{array}$ & [83] \\
\hline MRG-106 & miR-155 inhibitor & Mycosis fungoides & 38 & NA & NA & Pruritus, tumor flare & [84] \\
\hline DS-3201b & EZH1/2 dual inhibitor & PTL, AITL, DLBCL, FL, MZL & 15 & $53 \%$ & $6.6 \%$ & Pneumonia & [85] \\
\hline Apatinib & VEGFR-2 tyrosine kinase inhibitor & $\mathrm{R} / \mathrm{R} \mathrm{NHL}$ & 21 & $47.6 \%$ & $9.5 \%$ & None & [86] \\
\hline
\end{tabular}

Abbreviations: $N$ number of patients, $O R R$ overall response rate, $C R$ complete response rate, $A E$ adverse events, $R / R$ relapsed and refractory, $D L B C L$ diffuse large $B$ cell lymphoma, $C L L$ chronic leukemic leukemia, $t F L$ transformed follicular lymphoma, $F L$ follicular lymphoma, WM Waldenström's macroglobulinemia, $M Z L$ marginal zone lymphoma, MCL mantle cell lymphoma, PTL peripheral T cell lymphoma, AITL angio-immunoblastic T cell lymphoma, NHL non-Hodgkin lymphoma, VEGFR-2 vascular endothelial growth factor receptor-2 tyrosine kinase inhibitor, PI3K $\delta$ phosphatidylinositol 3 kinase delta, BET bromodomain and extraterminal protein inhibitor, $E Z H$ enhancer of zeste homolog, miR micro $\mathrm{RN}, D E$ dose escalation phase, NA data unavailable

\section{BTK inhibitor}

The Bruton's tyrosine kinase (BTK) enzyme is a regulator of B cell receptor-mediated signaling, and BTK inhibitors can effectively block several B cell functions and proliferation. BTK inhibitors like ibrutinib and acalabrutinib have been approved for B cell malignancies like CLL, MCL, marginal zone lymphoma (MZL), and WM. M7583 is a highly potent and selective second generation BTK inhibitor. In pre-clinical studies, it has shown selective kinase inhibition in comparison to ibrutinib and it does not inhibit the ADCC effects of rituximab in cell lysis studies [87]. In a phase 1 trial with M7583, 18 patients with $\mathrm{r} / \mathrm{r}$ NHL have been enrolled at 5 different dose levels, including $900 \mathrm{mg}$ daily the highest dose level [80]. The ORR was $50 \%$ with a disease control rate of $78 \%$ and two patients achieving CR. Two patients were reported to have treatment-related serious TEAE (treatment-emergent adverse event), and diarrhea was the most common TEAE in six patients (33\%). The MTD has not been reached with no dose-limiting toxicities reported. Responses were observed at all doses and both $300 \mathrm{mg}$ twice daily and $900 \mathrm{mg}$ daily were recommended as optimal biological doses to be evaluated in the doseexpansion phase.

\section{PI3K inhibitor}

ME 401 is a selective inhibitor of phosphatidylinositol 3 kinase p110 delta (PI3K $\delta$ ) expressed in B cell malignancies. PI3K $\delta$ is responsible for the homeostasis and function of B cells and is involved in interacting with the tumor microenvironment. In a first in human study with ME-401, 31 patients with $\mathrm{r} / \mathrm{r}$ FL and CLL were enrolled to receive escalating doses ranging from $60 \mathrm{mg}$ daily to $180 \mathrm{mg}$ daily [81]. The ORR was $83 \%$ including $75 \%$ in the FL patients and $100 \%$ in the CLL patients, with responses seen by cycle 2 in 20 out of 24 responding patients. Most common grade $\geq 3$ AEs reported were diarrhea in $16 \%$, rash in $10 \%$, colitis in $6 \%$, and stomatitis in $1 \%$, all occurring in cycle 3 or later. There were no DLTs reported and no further dose escalation above $180 \mathrm{mg}$ was planned. It was noted that the grade $\geq 3 \mathrm{AEs}$ had delayed onset after cycle 2 and were reversible with drug interruption and steroid use and attributed to regulatory $\mathrm{T}$ cell suppression. Among the 31 patients, 18 patients were switched to intermittent dosing schedule, with the drug being administered on days $1-7$ of a 28day cycle if they had not experienced grade $\geq 3$ AEs on continuous daily schedule [88]. Three patients (16\%) among the 18 patients developed grade 3 diarrhea in cycles 1 and 2 of the intermittent schedule and have been re-treated with no recurrence of symptoms. The ORR was 90\% among 30 evaluable patients. Another cohort of patients with relapsed FL, DLBCL, MZL, and MCL were enrolled with continuous dosing schedule for 2 weeks combined with rituximab and switched to intermittent schedule [88]. Ten out of the fifteen patients in this second cohort completed two cycles of continuous dosing and were switched to intermittent dosing. Only one patient out of 10 developed delayed grade 3 diarrhea and ORR was 70\% (7/10) in patients with FL/MZL [88]. Thus, intermittent scheduled dosing for patients developing AEs had a lower rate of toxicity with similar efficacy.

\section{BET inhibitor}

Bromodomain and extraterminal protein inhibitors can suppress B cell malignancies through epigenetic interactions causing proliferative pathway downregulation. INCB057643 is a selective small-molecule BET inhibitor. In a phase 1 study with advanced stage malignancies including lymphoma, a total of five lymphoma patients were enrolled [83]. Only one patient developed treatment-related AE in the form of thrombocytopenia. Among thelymphoma patients available for efficacy evaluation in the dose escalation cohort, one achieved CR and two had stable disease. 


\section{Autophagy enhancers}

Autophagy plays a vital role in cancer cell survival. Phosphatidylinositol-3-phosphate 5-kinase (PIKfyve) lipid kinase is an endosomal protein that regulates endolysosomal membrane transport and influences autophagy, by exposing damaged proteins to auto-phagolysosomes. LAM-002A has been identified as an inhibitor of PIKfyve and is cytotoxic in B cell lymphomas. This molecule disrupts lysosomal homeostasis, resulting in cytotoxicity with significant in vitro and in vivo antitumor activity in lymphoma models [89]. In a first in human study of 24 patients with $\mathrm{r} / \mathrm{r}$ B cell malignancies including DLBCL, tFL, MZL, MCL, FL, and CLL, sequential cohorts of patients received various dosing of LAM-002A from $50 \mathrm{mg}$ twice daily to $150 \mathrm{mg}$ twice daily [82]. Dose levels up to $100 \mathrm{mg}$ bid were well tolerated; however, at dose level 75 mg twice daily, nausea and vomiting led to drug discontinuation in two out of four patients. At a dose of $150 \mathrm{mg}$ twice daily, SAEs including nausea and diarrhea occurred in 4 out of 4 patients with 3 patients discontinuing therapy and one patient requiring dose reduction due to diarrhea. There were no dose-limiting toxicities at the $125 \mathrm{mg}$ twice daily dose and this was identified as the MTD. Enrollment is ongoing in a dose expansion at this dose level. At this dose level, one patient with DLBCL developed grade 4 tumor lysis syndrome. There have been partial metabolic responses noted in three patients with DLBCL treated at various doses (100 mg, $75 \mathrm{mg}$, and $125 \mathrm{mg}$ ). With the favorable toxicity profile and anti-tumor activity seen, further evaluation as monotherapy or in combination with chemoimmunotherapy is being considered.

\section{Micro-RNA}

MicroRNA miR-155 is overexpressed in cutaneous T cell lymphomas like Sezary syndrome and mycosis fungoides. MRG-106 is an inhibitor of miR-155 and has been evaluated in a phase 1 trial as an intralesional, subcutaneous (SC), or intravenous (IV) rapid bolus or 2-h infusion [84]. Thirty-eight patients received IV or SC treatments with no SAEs attributed to MRG-106 at 22 months on study. Twenty-nine out of the 32 patients had improvement in modified Severity Weighted Assessment Tool (mSWAT) with 11 of the 21 patients receiving more than 1 month of therapy achieving greater than $50 \%$ reduction in mSWAT score. The reduction in mSWAT scores correlated with improvement in the quality of life measured by the Skindex-29 total score. MRG-106 has an acceptable toxicity profile, with clinical activity and encouraging improvement in quality of life.

\section{Conclusion}

Relapsed and refractory lymphoma management remains a major treatment challenge. Although the addition of rituximab improved outcomes in patients with B cell lymphomas, a significant number of patients are rituximab refractory at the time of relapse. The development and approval of newer therapies including cellular therapy in the form of CAR T cells, the immunomodulator lenalidomide, the antibody-drug conjugate brentuximab, and the BTK inhibitor ibrutinib have further improved the outcomes of patients with relapsed disease in the last decade. Despite incorporating these agents into treatment at relapse, many patients will have poor outcomes at relapse with some unable to tolerate these therapies due to toxicity. The novel approaches described above have been designed to avoid the toxicities seen in current treatment options while some are targeting the disease by an entirely different approach. The promising efficacy demonstrated by these new treatments requires further evaluation in phase 2 or phase 3 trials. These therapies may ultimately enhance the efficacy of standard treatment options and further evaluation in combination approaches will be needed.

\section{Acknowledgements \\ None}

Authors' contributions

SA wrote the manuscript. KM reviewed and edited the manuscript. Both authors read and approved the final manuscript.

\section{Funding}

None

Availability of data and materials

Attached data

Ethics approval and consent to participate

Not required

Consent for publication

Yes

Competing interests

The authors declare that they have no competing interests.

Received: 2 April 2019 Accepted: 14 June 2019

Published online: 25 July 2019

\section{References}

1. Robert C, Long GV, Brady B, Dutriaux C, Maio M, Mortier L, et al. Nivolumab in previously untreated melanoma without BRAF mutation. N Engl J Med. 2015;372(4):320-30.

2. Gandhi L, Garassino MC. Pembrolizumab plus chemotherapy in lung cancer. N Engl J Med. 2018;379(11):e18.

3. Hodi FS, O'Day SJ, McDermott DF, Weber RW, Sosman JA, Haanen JB, et al. Improved survival with ipilimumab in patients with metastatic melanoma. N Engl J Med. 2010;363(8):711-23.

4. Mittal D, Gubin MM, Schreiber RD, Smyth MJ. New insights into cancer immunoediting and its three component phases--elimination, equilibrium and escape. Curr Opin Immunol. 2014;27:16-25.

5. Schreiber RD, Old $L$ J, Smyth MJ. Cancer immunoediting: integrating immunity's roles in cancer suppression and promotion. Science (New York, NY). 2011;331(6024):1565-70.

6. Cohen JE, Merims S, Frank S, Engelstein R, Peretz T, Lotem M. Adoptive cell therapy: past, present and future. Immunotherapy. 2017;9(2):183-96.

7. FDA approves tisagenlecleucel for B-cell ALL and tocilizumab for cytokine release syndrome [press release]. https:/www.fda.gov/drugs/informationondrugs/ approveddrugs/ucm574154.htm, Accessed 3 Mar 20192017. 
8. FDA approves tisagenlecleucel for adults with relapsed or refractory large B-cell lymphoma [press release]. https:/wwww.fda.gov/drugs/informationondrugs/ approveddrugs/ucm606540.htm, Accessed 3 Mar 20192018.

9. Schuster SJ, Bishop MR, Tam CS, Waller EK, Borchmann P, McGuirk JP, et al. Tisagenlecleucel in adult relapsed or refractory diffuse large B-cell lymphoma. N Engl J Med. 2019;380(1):45-56.

10. FDA approves CAR-T cell therapy to treat adults with certain types of large Bcell lymphoma [press release]. https:/www.fda.gov/newsevents/newsroom/ pressannouncements/ucm581216.htm, Accessed 30 Mar 20192017.

11. Neelapu SS, Locke FL, Bartlett NL, Lekakis LJ, Miklos DB, Jacobson CA, et al. Axicabtagene ciloleucel CAR T-cell therapy in refractory large B-cell lymphoma. N Engl J Med. 2017;377(26):2531-44.

12. Abramson JS, Gordon LI, Palomba ML, Lunning MA, Arnason JE, ForeroTorres A, et al. Updated safety and long term clinical outcomes in TRANSCEND NHL 001, pivotal trial of lisocabtagene maraleucel (JCAR017) in R/R aggressive NHL. J Clin Oncol. 2018;36(15_suppl):7505

13. Locke FL, Ghobadi A, Jacobson CA, Miklos DB, Lekakis $\amalg$, Oluwole OO, et al. Long-term safety and activity of axicabtagene ciloleucel in refractory large B-cell lymphoma (ZUMA-1): a single-arm, multicentre, phase 1-2 trial. Lancet Oncol. 2019;20(1):31-42.

14. Borchmann P. An updated analysis of JULIET, a global pivotal phase 2 trial of tisagenlecleucel in adult patients with relapsed or refractory $(r / r)$ diffuse large B-cell lymphoma (DLBCL). HemaSphere. 2018;2(S1):1-1113.

15. Hopfinger $G$, Jäger U, Worel N. CAR-T Cell Therapy in diffuse large B cell lymphoma: hype and hope. HemaSphere. 2019;3(2):e185.

16. Santomasso BD, Park JH, Salloum D, Riviere I, Flynn J, Mead E, et al. Clinical and biological correlates of neurotoxicity associated with CAR T-cell therapy in patients with B-cell acute lymphoblastic leukemia. Cancer Discov. 2018; 8(8):958-71.

17. Liu H, Horan LH, Grupp SA, Barrett DM, Liu C. Abstract 1537: Anti-CD19 ARTEMIS $^{\text {TM }} T$ cells prevent excessive inflammatory cytokine release, including IL-6, in a co-culture model of CRS. Cancer Res. 2018;78(13 Supplement):1537.

18. Ying ZT, Long L, Liu H, Zhang M, He P, Rizzieri D, et al. ET190L1-ARTEMIS T cell therapy to induce complete remission of relapsed and refractory $(r / r) B-$ cell lymphoma with no cytokine release syndrome in the first-in-human clinical study. J Clin Oncol. 2018;36(15_suppl):3049.

19. Ying Z, Long L, Liu H, Song Y, Rizzieri DA, Nejadnik B, et al. ET190L1-Artemis $T$ cell therapy results in durable disease remissions with no cytokine release syndrome or neurotoxicity in patients with relapsed and refractory B-cell lymphoma. Blood. 2018;132(Suppl 1):1689.

20. Shalabi H, Kraft IL, Wang HW, Yuan CM, Yates B, Delbrook C, et al. Sequential loss of tumor surface antigens following chimeric antigen receptor T-cell therapies in diffuse large B-cell lymphoma. Haematologica. 2018;103(5):e215-e8.

21. Fry TJ, Shah NN, Orentas RJ, Stetler-Stevenson M, Yuan CM, Ramakrishna S, et al. CD22-targeted CAR T cells induce remission in B-ALL that is naive or resistant to CD19-targeted CAR immunotherapy. Nat Med. 2017;24:20.

22. Sotillo E, Barrett DM, Black KL, Bagashev A, Oldridge D, Wu G, et al. Convergence of acquired mutations and alternative splicing of CD19 enables resistance to CART-19 immunotherapy. Cancer Discov. 2015;5(12):1282-95.

23. Hossain N, Sahaf B, Abramian M, Spiegel JY, Kong K, Kim S, et al. Phase experience with a bi-specific CAR targeting CD19 and CD22 in adults with B-cell malignancies. Blood. 2018;132(Suppl 1):490.

24. Shah NN, Zhu F, Taylor C, Schneider D, Krueger W, Worden A, et al. A phase 1 study with point-of-care manufacturing of dual targeted, tandem antiCD19, anti-CD20 chimeric antigen receptor modified T (CAR-T) cells for relapsed, refractory, non-Hodgkin lymphoma. Blood. 2018;132(Suppl 1):4193.

25. Ardeshna K, Marzolini MAV, Osborne W, Al-Hajj M, Thomas S, Faulkner J, et al. Study of AUTO3, the first bicistronic chimeric antigen receptor (CAR) targeting CD19 and CD22, followed by anti-PD1 consolidation in patients with relapsed/refractory $(r / r)$ diffuse large $B$ cell lymphoma (DLBCL): Alexander Study. Blood. 2018;132(Suppl 1):1679.

26. Park JH, Palomba ML, Batlevi CL, Riviere I, Wang X, Senechal B, et al. A phase I first-in-human clinical trial of CD19-targeted 19-28z/4-1BBL "armored" CAR T cells in patients with relapsed or refractory NHL and CLL including Richter's transformation. Blood. 2018;132(Suppl 1):224.

27. Akard LP, Jaglowski S, Devine SM, McKinney MS, Vasconcelles M, Huet $H$, et al. ACTR087, autologous T lymphocytes expressing antibody coupled Tcell receptors (ACTR), induces complete responses in patients with relapsed or refractory CD20-positive B-cell lymphoma, in combination with rituximab. Blood. 2017;130(Suppl 1):580.
28. Flinn IW, Cohen JB, Akard LP, Jaglowski S, Vasconcelles M, Ranger A, et al. Preliminary clinical results of a phase 1 study evaluating the safety and antitumor activity of ACTR707 in combination with rituximab in subjects with relapsed or refractory CD20+ B-cell lymphoma. Blood. 2018;132(Suppl 1):2966.

29. Zhao Z, Condomines M, van der Stegen SJC, Perna F, Kloss CC, Gunset G, et al. Structural design of engineered costimulation determines tumor rejection kinetics and persistence of CAR T cells. Cancer Cell. 2015;28(4):415-28.

30. Grupp SA, Maude SL, Shaw PA, Aplenc R, Barrett DM, Callahan C, et al. Durable remissions in children with relapsed/refractory ALL treated with $T$ cells engineered with a CD19-targeted chimeric antigen receptor (CTL019). Blood. 2015;126(23):681.

31. Huet HA, Judge C, Barnitz RA, Boomer R, McGinness K, Shin J, et al. Targeting CD20+ Relapsed refractory B cell lymphoma with ACTR087, antibody-coupled T-cell receptor (ACTR) engineered autologous T cells, in combination with rituximab. Blood. 2016;128(22):3512.

32. Kudo K, Imai C, Lorenzini P, Kamiya T, Kono K, Davidoff AM, et al. T Lymphocytes expressing a CD16 signaling receptor exert antibodydependent cancer cell killing. Cancer Res. 2014;74(1):93-103.

33. Goebeler M-E, Knop S, Viardot A, Kufer P, Topp MS, Einsele H, et al. Bispecific T-cell engager (BiTE) antibody construct blinatumomab for the treatment of patients with relapsed/refractory non-Hodgkin lymphoma: final results from a phase I study. J Clin Oncol. 2016;34(10):1104-11.

34. Viardot A, Goebeler ME, Hess G, Neumann S, Pfreundschuh M, Adrian N, et al. Phase 2 study of the bispecific T-cell engager (BiTE) antibody blinatumomab in relapsed/refractory diffuse large B-cell lymphoma. Blood. 2016;127(11):1410-6.

35. Hutchings M, lacoboni G, Morschhauser F, Offner F, Sureda A, Salles GA, et al. CD20-Tcb (RG6026), a novel "2:1" format T-cell-engaging bispecific antibody, induces complete remissions in relapsed/refractory B-cell nonHodgkin's lymphoma: preliminary results from a phase I first in human trial. Blood. 2018;132(Suppl 1):226

36. Budde LE, Sehn LH, Assouline S, Flinn IW, Isufi I, Yoon S-S, et al. Mosunetuzumab, a full-length bispecific CD20/CD3 antibody, displays clinical activity in relapsed/refractory B-cell non-Hodgkin lymphoma (NHL): interim safety and efficacy results from a phase 1 study. Blood. 2018; 132(Suppl 1):399.

37. Caimi P, Kahl BS, Hamadani M, Carlo-Stella C, He S, Ungar D, et al. Safety and efficacy of Adct-402 (loncastuximab tesirine), a novel antibody drug conjugate, in relapsed/refractory follicular lymphoma and mantle cell lymphoma: interim results from the phase 1 first-in-human study. Blood. 2018;132(Suppl 1):2874.

38. Collins GP, Horwitz SM, Davies A, Karnad A, Samaniego F, Spira Al, et al. Adct-301 (camidanlumab tesirine), a novel pyrrolobenzodiazepine-based CD25-targeting antibody drug conjugate, in a phase 1 study of relapsed/ refractory non-Hodgkin lymphoma shows activity in T-cell lymphoma. Blood. 2018;132(Suppl 1):1658.

39. Hamadani M, Collins GP, Samaniego F, Spira Al, Davies A, Radford J, et al. Phase 1 study of Adct-301 (camidanlumab tesirine), a novel pyrrolobenzodiazepine-based antibody drug conjugate, in relapsed/ refractory classical Hodgkin lymphoma. Blood. 2018;132(Suppl 1):928.

40. Fanale MA, Hamlin PA, Park SI, Persky DO, Higgins JP, Burnett C, et al. Safety and efficacy of anti-CD20 immunotoxin MT-3724 in relapsed/refractory (R/R) B-cell non-Hodgkin lymphoma (NHL) in a phase I study. J Clin Oncol. 2018; 36(15_suppl):7580.

41. Advani R, Flinn I, Popplewell L, Forero A, Bartlett NL, Ghosh N, et al. CD47 Blockade by Hu5F9-G4 and rituximab in non-Hodgkin's lymphoma. N Engl J Med. 2018;379(18):1711-21.

42. Herrera AF, Patel MR, Burke JM, Advani RH, Cheson BD, Sharman JP, et al. A phase I study of the anti-CD79b THIOMAB-drug conjugate DCDS0780A in patients (pts) with relapsed or refractory B-cell non-Hodgkin's lymphoma (BNHL). Blood. 2017;130(Suppl 1):4129.

43. Kolstad A, Madsbu U, Beasley M, Bayne M, Illidge TM, O'Rourke N, et al. 177 Lu-lilotomab satetraxetan, a novel CD37-targeted antibody-radionuclide conjugate in relapsed non-Hodgkin's lymphoma (NHL): updated results of an ongoing phase I/II study (LYMRIT 37-01). Blood. 2017;130(Suppl 1):2769.

44. Mossner E, Brunker P, Moser S, Puntener U, Schmidt C, Herter S, et al. Increasing the efficacy of $C D 20$ antibody therapy through the engineering of a new type II anti-CD20 antibody with enhanced direct and immune effector cell-mediated B-cell cytotoxicity. Blood. 2010;115(22):4393-402.

45. Nagorsen D, Kufer P, Baeuerle PA, Bargou R. Blinatumomab: a historical perspective. Pharmacol Ther. 2012;136(3):334-42. 
46. Nagorsen D, Baeuerle PA. Immunomodulatory therapy of cancer with T cellengaging BiTE antibody blinatumomab. Exp Cell Res. 2011;317(9):1255-60.

47. Haas C, Krinner E, Brischwein K, Hoffmann P, Lutterbuse R, Schlereth B, et al. Mode of cytotoxic action of T cell-engaging BiTE antibody MT110. Immunobiology. 2009;214(6):441-53.

48. Löffler A, Kufer P, Lutterbüse R, Zettl F, Daniel PT, Schwenkenbecher JM, et al. A recombinant bispecific single-chain antibody, CD19 $\times$ CD3, induces rapid and high lymphoma-directed cytotoxicity by unstimulated $\mathrm{T}$ lymphocytes. Blood. 2000;95(6):2098-103.

49. Schlereth B, Quadt C, Dreier T, Kufer P, Lorenczewski G, Prang N, et al. T-cell activation and B-cell depletion in chimpanzees treated with a bispecific anti-CD19/anti-CD3 single-chain antibody construct. Cancer Immunol Immunother. 2006;55(5):503-14.

50. Bacac M, Fauti T, Sam J, Colombetti S, Weinzierl T, Ouaret D, et al. A novel carcinoembryonic antigen T-cell bispecific antibody (CEA TCB) for the treatment of solid tumors. Clin Cancer Res. 2016;22(13):3286-97.

51. Bacac M, Klein C, Umana P. CEA TCB: A novel head-to-tail 2:1 T cell bispecific antibody for treatment of CEA-positive solid tumors. Oncoimmunology. 2016;5(8):e1203498.

52. Bacac M, Colombetti S, Herter S, Sam J, Perro M, Chen S, et al. CD20-TCB with obinutuzumab pretreatment as next-generation treatment of hematologic malignancies. Clin Cancer Res. 2018;24(19):4785-97.

53. Sun LL, Ellerman D, Mathieu M, Hristopoulos M, Chen X, Li Y, et al. AntiCD20/CD3 T cell-dependent bispecific antibody for the treatment of B cell malignancies. Sci Transl Med. 2015;7(287):287ra70.

54. Zammarchi F, Corbett S, Adams L, Tyrer PC, Kiakos K, Janghra N, et al. ADCT-402, a PBD dimer-containing antibody drug conjugate targeting CD19-expressing malignancies. Blood. 2018. https://doi.org/10.1182/blood2017-10-813493.

55. Radford J, Kahl BS, Hamadani M, Carlo-Stella C, Caimi P, Ardeshna KM, et al. Interim results from the first-in-human clinical trial of Adct-402 (loncastuximab tesirine), a novel pyrrolobenzodiazepine-based antibody drug conjugate, in relapsed/refractory diffuse large B-cell lymphoma. Blood. 2018;132(Suppl 1):398.

56. Strauchen JA, Breakstone BA. IL-2 receptor expression in human lymphoid lesions. Immunohistochemical study of 166 cases. Am J Pathol. 1987;126(3): 506-12.

57. Flynn MJ, Zammarchi F, Tyrer PC, Akarca AU, Janghra N, Britten CE, et al. ADCT-301, a pyrrolobenzodiazepine (PBD) dimer-containing antibody-drug conjugate (ADC) targeting CD25-expressing hematological malignancies. Mol Cancer Ther. 2016;15(11):2709-21.

58. Willert EK, Robinson GL, Rajagopalan S, Brieschke B, Erdman J, Neill J, et al. Abstract 2477: Engineered toxin bodies: a next-generation immunotoxin scaffold with novel immuno-oncology functionality. Cancer Res. 2015;75(15 Supplement):2477.

59. Chao MP, Alizadeh AA, Tang C, Myklebust JH, Varghese B, Gill S, et al. AntiCD47 Antibody synergizes with rituximab to promote phagocytosis and eradicate non-Hodgkin lymphoma. Cell. 2010;142(5):699-713.

60. Liu J, Wang L, Zhao F, Tseng S, Narayanan C, Shura L, et al. pre-clinical development of a humanized anti-CD47 antibody with anti-cancer therapeutic potential. PloS one. 2015;10(9):e0137345-e.

61. Sharma P, Allison JP. The future of immune checkpoint therapy. Science. 2015;348(6230):56-61.

62. Keir ME, Butte MJ, Freeman GJ, Sharpe AH. PD-1 and its ligands in tolerance and immunity. Annu Rev Immunol. 2008;26:677-704.

63. Green MR, Monti S, Rodig SJ, Juszczynski P, Currie T, O'Donnell E, et al. Integrative analysis reveals selective 9p24.1 amplification, increased PD-1 ligand expression, and further induction via JAK2 in nodular sclerosing Hodgkin lymphoma and primary mediastinal large B-cell lymphoma. Blood. 2010;116(17):3268-77.

64. Roemer MG, Advani RH, Ligon AH, Natkunam $Y$, Redd RA, Homer $\mathrm{H}$, et al. PD-L1 and PD-L2 genetic alterations define classical Hodgkin lymphoma and predict outcome. J Clin Oncol. 2016;34(23):2690-7.

65. Armand P, Engert A, Younes A, Fanale M, Santoro A, Zinzani PL, et al. Nivolumab for relapsed/refractory classic Hodgkin lymphoma after failure of autologous hematopoietic cell transplantation: extended follow-up of the multicohort single-arm phase II CheckMate 205 Trial. J Clin Oncol. 2018; 36(14):1428-39.

66. Chen R, Zinzani PL, Fanale MA, Armand P, Johnson NA, Brice P, et al. Phase II study of the efficacy and safety of pembrolizumab for relapsed/refractory classic Hodgkin lymphoma. J Clin Oncol. 2017;35(19):2125-32.
67. Ansell S, Gutierrez ME, Shipp MA, Gladstone D, Moskowitz A, Borello I, et al. A phase 1 study of nivolumab in combination with ipilimumab for relapsed or refractory hematologic malignancies (CheckMate 039). Blood. 2016; 128(22):183.

68. Herrera AF, Moskowitz AJ, Bartlett NL, Vose JM, Ramchandren R, Feldman $T A$, et al. Interim results of brentuximab vedotin in combination with nivolumab in patients with relapsed or refractory Hodgkin lymphoma. Blood. 2018;131(11):1183-94.

69. Ramchandren R, Fanale MA, Rueda A, Armand $P$, Trněný $M$, Feldman TA, et al. Nivolumab for newly diagnosed advanced-stage classical Hodgkin lymphoma (cHL): results from the phase 2 Checkmate 205 Study. Blood. 2017;130(Suppl 1):651.

70. Chapuy B, Roemer MG, Stewart C, Tan Y, Abo RP, Zhang L, et al. Targetable genetic features of primary testicular and primary central nervous system lymphomas. Blood. 2016;127(7):869-81.

71. Zinzani PL, Ribrag V, Moskowitz CH, Michot JM, Kuruvilla J, Balakumaran A, et al. Safety and tolerability of pembrolizumab in patients with relapsed/ refractory primary mediastinal large B-cell lymphoma. Blood. 2017;130(3): 267-70.

72. Nayak L, Iwamoto FM, LaCasce A, Mukundan S, Roemer MGM, Chapuy B, et al. PD-1 blockade with nivolumab in relapsed/refractory primary central nervous system and testicular lymphoma. Blood. 2017;129(23):3071-3.

73. Chen BJ, Chapuy B, Ouyang J, Sun HH, Roemer MG, Xu ML, et al. PD-L1 expression is characteristic of a subset of aggressive B-cell lymphomas and virus-associated malignancies. Clin Cancer Res. 2013;19(13):3462-73.

74. Van Roosbroeck K, Ferreiro JF, Tousseyn T, van der Krogt JA, Michaux L, Pienkowska-Grela B, et al. Genomic alterations of the JAK2 and PDL loci occur in a broad spectrum of lymphoid malignancies. Genes Chromosomes Cancer. 2016;55(5):428-41.

75. Lesokhin AM, Ansell SM, Armand P, Scott EC, Halwani A, Gutierrez M, et al. Nivolumab in patients with relapsed or refractory hematologic malignancy: preliminary results of a phase Ib study. J Clin Oncol. 2016;34(23):2698-704.

76. Andorsky DJ, Yamada RE, Said J, Pinkus GS, Betting DJ, Timmerman JM. Programmed death ligand 1 is expressed by non-Hodgkin lymphomas and inhibits the activity of tumor-associated T cells. Clin Cancer Res. 2011;17(13):4232-44.

77. Smeltzer JP, Jones JM, Ziesmer SC, Grote DM, Xiu B, Ristow KM, et al. Pattern of CD14+ follicular dendritic cells and PD1+ T cells independently predicts time to transformation in follicular lymphoma. Clin Cancer Res. 2014;20(11):2862-72.

78. Yang ZZ, Grote DM, Ziesmer SC, Xiu B, Novak AJ, Ansell SM. PD-1 expression defines two distinct T-cell sub-populations in follicular lymphoma that differentially impact patient survival. Blood Cancer J. 2015;5:e281.

79. Palomba ML, Till BG, Park SI, Morschhauser F, Cartron G, Marks R, et al. A phase lb study evaluating the safety and clinical activity of atezolizumab combined with obinutuzumab in patients with relapsed or refractory nonHodgkin lymphoma (NHL). Hematol Oncol. 2017;35(S2):137-8.

80. Jurczak W, Rule S, Townsend W, Tucker D, Sarholz B, Scheele J, et al. A phase $1 / / 1$, first in human trial of the Bruton's tyrosine kinase inhibitor M7583 in patients with B-cell malignancies. Blood. 2018;132(Suppl 1):4161.

81. Soumerai JD, Pagel JM, Jagadeesh D, Salman HS, Kenkre VP, Asch AS, et al. Initial results of a dose escalation study of a selective and structurally differentiated PI3KS inhibitor, ME-401, in relapsed/refractory (R/R) follicular lymphoma (FL) and chronic lymphocytic leukemia (CLL)/small lymphocytic lymphoma (SLL). J Clin Oncol. 2018;36(15_suppl):7519.

82. Harb WA, Diefenbach CS, Lakhani N, Rutherford SC, Schreeder MT, Ansell SM, et al. Phase 1 clinical safety, pharmacokinetics (PK), and activity of apilimod dimesylate (LAM-002A), a first-in-class inhibitor of phosphatidylinositol-3-phosphate 5-kinase (PIKfyve), in patients with relapsed or refractory B-cell malignancies. Blood. 2017;130(Suppl 1):4119.

83. Forero-Torres A, Rosen S, Smith DC, Lesser G, Peguero J, Gupta S, et al. Preliminary results from an ongoing phase 1/2 study of INCB057643, a bromodomain and extraterminal (BET) protein inhibitor, in patients (pts) with advanced malignancies. Blood. 2017;130(Suppl 1):4048.

84. Querfeld C, Foss FM, Kim YH, Pinter-Brown L, William BM, Porcu P, et al. Phase 1 trial of cobomarsen, an inhibitor of Mir-155, in cutaneous T cell lymphoma. Blood. 2018;132(Suppl 1):2903.

85. Maruyama D, Tobinai K, Makita S, Ishida T, Kusumoto S, Ishitsuka K, et al. First-in-human study of the EZH1/2 dual inhibitor DS-3201b in patients with relapsed or refractory non-Hodgkin lymphomas - preliminary results. Blood. 2017;130(Suppl 1):4070. 
86. Li L, Xiao S, Young KH, Zhang L, Li X, Fu X, et al. Efficacy and safety of novel targeted drug' apatinib in relapse or refractory non-Hodgkin lymphoma: an open label, single-armed, exploratory study. Blood. 2017;130(Suppl 1):1548.

87. Goodstal SM, Ma J, Lin J, Crandall T, Crowley L, Bender A, et al. M7583 is a highly selective and potent second generation BTK inhibitor for treatment of B-cell malignancies. Blood. 2017;130(Suppl 1):3845.

88. Zelenetz AD, Soumerai JD, Jagadeesh D, Reddy N, Stathis A, Asch AS, et al. Preliminary safety and efficacy results with an intermittent schedule of the PI3kठ inhibitor ME-401 alone or in combination with rituximab for B-cell malignancies. Blood. 2018;132(Suppl 1):2893.

89. Gayle S, Landrette S, Beeharry N, Conrad C, Hernandez M, Beckett P, et al. Identification of apilimod as a first-in-class PIKfyve kinase inhibitor for treatment of B-cell non-Hodgkin lymphoma. Blood. 2017;129(13):1768-78.

\section{Publisher's Note}

Springer Nature remains neutral with regard to jurisdictional claims in published maps and institutional affiliations.

Ready to submit your research? Choose BMC and benefit from:

- fast, convenient online submission

- thorough peer review by experienced researchers in your field

- rapid publication on acceptance

- support for research data, including large and complex data types

- gold Open Access which fosters wider collaboration and increased citations

- maximum visibility for your research: over $100 \mathrm{M}$ website views per year

At BMC, research is always in progress.

Learn more biomedcentral.com/submissions 